\title{
PENGABDIAN DONOR DARAH PADA MASYARAKAT "SETETES DARAH UNTUK KEMANUSIAAN DITENGAH PANDEMI COVID-19 “
}

\section{COMMUNITY DONATION OF BLOOD DONATION "DROP BLOOD FOR HUMANITY IN THE MIDDLE OF THE COVID-19 PANDEMIC"}

\author{
Linayati Lestari $^{1 *}$, Rona Tanjung1, Karol Teovani Lodan², Rini Elfina ${ }^{3}$ \\ ${ }^{1}$ (Universitas Riau Kepulauan, Indonesia); ${ }^{2}$ (Universitas Putera Batam, Indonesia); ${ }^{3}$ (Universitas Ibnu Sina, \\ Indonesia) \\ ${ }^{1}$ linayati@fisip.unrika.ac.id; ${ }^{1}$ ronatanjung07@gmail.com; ${ }^{2}$ karol.lodan@gmail.com; \\ rini.elfina@uis.ac.id
}

\begin{abstract}
Abstrak
Kegiatan pengabdian pada masyarakat ini bertujuan untuk menyosialisasikan donor darah kepada masyarakat ditengah pandemi covid-19 dan sebagai upaya membantu ketersediaan stok darah di Kota Batam. Selain itu tujuan lainnya adalah sebagai upaya mendorong peningkatan kepedulian semua elemen masyarakat dalam kegiatan sosial ditengah masa pandemi covid-19 serta mewujudkan pelaksanaan program pengabdian kepada masyarakat oleh Dosen di Perguruan Tinggi masing-masing, terutama di Kota Batam, Provinsi Kepulauan Riau. Melihat situasi menipisnya stok darah di Palang Merah Indonesia Kota Batam membuat dosen-dosen dengan penuh kesadaran tergerak untuk membantu ketersediaan stok darah tersebut. Kegiatan "Donor Darah" ini dilaksanakan pada bulan September 2020 di Atrium 2 Grand Mall Batam, Kecamatan Lubuk Baja, Kota Batam. Bentuk kegiatan merupakan kegiatan donor darah. Peserta donor darah yang berpartisipasi dari berbagai pihak. Adapun informasi mengenai peserta donor darah adalah sebagai berikut: Peserta yang mendaftar berjumlah 97 orang; peserta yang dinyatakan boleh mendonorkan darah berjumlah 65 orang. Secara umum pelaksanaan kegiatan donor darah "Setetes Darah untuk Kemanusiaan" terlaksana sesuai rencana dan berjalan dengan lancar. Terlaksananya kegiatan tentunya tidak lepas dari dukungan berbagai pihak, baik para peserta donor darah, dosen-dosen, donator, PMI Kota Batam, Polsek Lubuk Baja, panitia dari Universitas Riau Kepulauan (UNRIKA), Universitas Putera Batam (UPB), dan Universitas Ibnu Sina (UIS). Semoga kegiatan sosial donor darah dapat pula terlaksana di masa yang akan datang sebagai wadah sosial untuk kemanusiaan.
\end{abstract}

Kata Kunci ; Pengabdian; kemanusiaan; donor darah; pandemi.

\begin{abstract}
This service activity aims to disseminate blood donations to the community amid the Covid-19 pandemic and as an effort to help the availability of blood stocks in Batam City. Another goal is to encourage increased awareness of all elements of society in social activities in the midst of the Covid-19 pandemic and to realize the implementation of community service programs by lecturers at their respective universities, especially in Batam City, Riau Islands Province. Seeing the situation of depletion of blood stocks at the Indonesian Red Cross in Batam City made lecturers with full awareness moved to help the availability of this blood stock. This "Blood Donation" activity was held in September 2020 at Atrium 2 Grand Mall Batam, Lubuk Baja District, Batam City. The form of the activity is blood donation. Blood donation participants who participated from various parties. The information regarding blood donor participants is as follows: Participants who registered were 97 people; participants who were declared allowed to donate blood totaled 65 people. In general, the blood donation activity "A Drop of Blood for Humanity" was carried out according to plan and went well. The implementation of this activity is of course inseparable from the support of various parties, including blood donor participants, lecturers, donors, PMI Batam City, Lubuk Baja Police, committees from the University of Riau Islands (UNRIKA), University of Putera Batam (UPB), and University of Ibnu. Sina (UIS). Hopefully, blood donation social activities can also be carried out in the future as a social forum for humanity.
\end{abstract}

Keywords ; Devotion; blood donors; pandemic. 


\section{PENDAHULUAN}

Komponen terpenting dalam tubuh manusia salah satunya adalah darah. Keputusan untuk menyumbangkan darah melalui donor darah dapat menyelamatkan satu kehidupan, atau bahkan beberapa nyawa sekaligus. tidak hanya menguntungkan bagi penerima darah,akan tetapi donor darah juga memberikan manfaat bagi pendonornya. Dikutip dari laman Tempo, data dari WHO menunjukkan bahwa kebutuhan darah di Indonesia per tahun mencapai sekitar 5,1 juta kantong darah, sementara yang terpenuhi hanya sekitar 4,2 juta kantong darah. Angka tersebut mengakibatkan banyak rumah sakit masih sering mengalami kesulitan dalam memenuhi kebutuhan transfusi darah. Donor darah adalah kegiatan menyalurkan darah atau produk berbasis darah dari satu orang ke sistem peredaran orang lainnya. Angka kematian akibat tidak tersedianya cadangan darah untuk transfusi pada negara berkembang relatif tinggi. Indonesia memiliki tingkat penyumbang sebanyak 6-10 orang per 1000 penduduk yang jauh lebih kecil dibandingkan dengan beberapa negara kecil di Asia (Situmorang et al., 2020).

Menurut Pribadi et al., (2018) Rata-rata volume darah manusia adalah 6-8\% dari berat tubuh atau sekitar 5-6 liter yang didominasi oleh komponen plasma darah (55\%) dan eritrosit (45\%). Kekurangan jumlah darah di dalam tubuh akan berakibat pada kerusakan jaringan dan kegagalan fungsi organ-organ vital penyebab kematian. Kekurangan pasokan darah dalam tubuh dapat diatasi dengan penambahan volume darah dari luar berupa darah pendonor. Namun demikian, darah bukan benda sintetis yang dapat direkayasa dan hanya diproduksi oleh manusia sehingga penambahan darah hanya dapat dilakukan dengan menambahan darah yang berasal dari manusia. Minimnya ketersediaan darah diperkirakan akibat dari rendahnya kesadaran masyarakat untuk mendonorkan darahnya. Padahal, manfaat donor darah tidak hanya dirasakan oleh penerima donor saja, melainkan juga pendonor. Adapun manfaat ganda yang diperoleh para pendonor yakni menunjukkan kepedulian yang besar dalam membantu ketersediaan darah bagi masyarakat yang membutuhkan. Selain itu, mengutip pada artikel "5 manfaat donor darah bagi kesehatan anda" (https://hellosehat.com/), disampaikan bahwa manfaat kesehatan bagi pendonor misalnya, menurunkan resiko kanker, mebantu menurunkan berat badan, membuat tubuh lebih sehat secara psikologis, dan perpanjangan usia, menurunkan risiko terkena penyakit jantung dan pembuluh darah, mendeteksi penyakit serius. 
Tentunya tidak semua masyarakat bisa mendonorkan darahnya hal ini sangat dipengaruhi pula oleh riwayat kesehatan yang direkomendasikan oleh Palang Merah Indonesia maupun rumah sakit.

Sehubungan dengan stok darah yang menipis juga dirasakan Palang Merah Indonesia Kota Batam. Apalagi dalam kondisi pandemi covid-19 yang mewabah seperti ini, membuat ketakutan atau kecemasan bagi masyarakat dalam mendonorkan darahnya. Padahal menurut Kepala Unit Transfusi Darah PMI Kota Batam, Dokter Novia, kalau donor darah tidak dapat menularkan Covid-19 (https://batampos.co.id/). Selain itu, proses pengambilan darah para pendonor selama masa pandemi covid-19 juga mengikuti protokol kesehatan. Informasi seperti inilah yang kiranya belum diketahui secara jelas oleh masyarakat Kota Batam.

Saat ini masyarakat yang mendonorkan darahnya hanya untuk keperluan pribadi atau sanak keluarga dan kerabat teman dekatnya. Dalam beberapa waktu ini untuk mengatasi kekosongan darah tersebut, PMI Kota Batam telah berkoordinasi dengan Brimob dan Yonif. Namun stok yang ada itupun hanya bisa untuk menyuplai darah ke rumah sakit. Palang Merah Indonesia Kota Batam tentunya sangat berharap, masyarakat Kota Batam yang memenuhi syarat kesehatan dapat kembali mendonorkan darahnya.

Melihat situasi menipisnya stok darah di Palang Merah Indonesia Kota Batam membuat dosen-dosen dengan penuh kesadaran tergerak untuk membantu ketersediaan stok darah tersebut. Dosen-dosen UNRIKA, UPB, dan UIS bekerjasama dengan PMI Kota Batam serta Alumni Taplai Lemhannas RI Kepri yang beranggotakan berbagai profesi dari unsur pemerintah daerah, tokoh agama, TNI, Polri, Dosen, Notaris, Guru, Wartawan, ormas dan lain sebagainya, menginisiasi adanya kegiatan donor darah. Dengan mengalang dukungan dari berbagai pihak, komunitas, organisasi pemerintah, masyarakat, TNI dan Polri, mengadakan kegiatan donor darah bertajuk "Setetes Darah untuk Kemanusiaan”. Kegiatan ini bekerjasama dengan Palang Merah Indonesia Kota Batam dengan menerapkan protokol kesehatan selama kegiatan berlangsung. Oleh karena itu dibutuhkan dukungan dari berbagai pihak tidak hanya para pendonor, melainkan dukungan pendanaan sehingga kegiatan tersebut dapat terselenggarakan dengan lancar dan sukses sesuai target stok darah yang diinginkan. Besar harapan kami banyak pihak yang tergerak dalam mendukung kegiatan mulia yang dilaksanakan ini. 
Tujuan kegiatan donor darah yang digagas oleh para Dosen bekerjasama dengan PMI Kota Batam, memiliki beberapa tujuan, diantaranya: sebagai upaya mensosialisasikan donor darah kepada masyarakat ditengah pandemi covid-19; sebagai upaya membantu ketersediaan stok darah; upaya mendorong peningkatan kepedulian semua elemen masyarakat dalam kegiatan sosial ditengah masa pandemi covid-19; serta mewujudkan pelaksanaan program pengabdian kepada masyarakat oleh Dosen sebagai wujud pemenuhan kewajiban tridarma perguruan tinggi, terutama di Kota Batam, Provinsi Kepulauan Riau.

\section{METODOLOGI}

Kegiatan bakti sosial donor darah telah dilaksanakan pada hari Minggu, 13 September 2020. Tempat kegiatan bakti sosial ini dilaksanakan di Grand Mall Kota Batam. Kegiatan pengabdian masyarakat ini direncanakan dalam waktu 2 minggu. Pelaksanaan Kegiatan meliputi kegiatan sebagai berikut :

a. Persiapan kegiatan dilakukan dengan melakukan kordinasi dengan PMI Kota Batam, alumni Taplai Lemhannas Kepri dan juga dosen - dosen di Kota Batam, persiapan ini dilakukan untuk menyiapkan sarana dan kelengkapan untuk kegiatan donor darah serta sosialisasi kegiatan tersebut

b. Kegiatan bakti sosial dilaksanakan sejak pukul 10.00 WIB - selesai di Grand mall, masyarakat yang ingin mendonorkan darahnya terlebih dulu didaftarkan oleh panitia, kemudian diperiksa kesehatannya oleh petugas PMI Kota Batam, jika memenuhi persyaratan melakukan pendonoran darah maka peserta dipersilakan untuk mendonorkan darahnya

c. Di akhir kegiatan peserta donor mendapatkan door prize sebagai bentuk apresiasi dalam kegiatan sosial ini.

\section{PEMBAHASAN}

Pengorganisasian atau pembentukan tim Pengabdian kepada Masyarakat berasal dari gabungan 3 Universitas (UNRIKA, UPB, UIS). Pengorganisasian ini bertujuan agar terdapat kejelasan dan tanggung jawab anggota tim antara tugas, wewenang, dan tanggungjawab sesuai dengan bidangnya. Menurut Kurniadin dan Machali (2012) pengorganisasian berarti menciptakan suatu struktur dengan bagian-bagian yang terintegrasi sehingga mempunyai hubungan yang saling memengaruhi satu sama lain. Dengan adanya struktur organisasi maka 
tugas pokok dan fungsi anggota yang terlibat akan semakin jelas dan mudah dipahami. Selain melibatkan Dosen, Mahasiswa, dan beberapa unsur lainnya, kegiatan ini juga melibatkan masyarakat luas. Oleh sebab itu koordinasi antara satu sama lain sangatlah perlu dilakukan. Selain koordinasi komunikasi sesama panitia juga diperlukan dengan mengutamakan protokol kesehatan dan keselamatan ditengah pandemi Covid-19 .

Kegiatan "Donor Darah" ini dilaksanakan pada bulan September 2020 di Atrium 2 Grand Mall Batam, Kecamatan Lubuk Baja, Kota Batam. Bentuk kegiatan merupakan kegiatan donor darah. Peserta donor darah yang berpartisipasi dari berbagai pihak. Adapun informasi mengenai peserta donor darah adalah sebagai berikut: peserta yang mendaftar berjumlah 97 orang; peserta yang dinyatakan boleh mendonorkan darah berjumlah 65 orang. Peserta yang mendaftar namun setelah dilakukan pemeriksaan ternyata tidak dapat melakukan donor darah, dikarenakan: adanya kendala kesehatan; telah donor darah tidak lebih dari 2 (dua) bulan; dan telah makan tidak lebih dari 3 (tiga) jam sebelumnya.

Mengingat pelaksanaan kegiatan Donor Darah dilakukan saat pandemi Covid-19 maka protokol kesehatan sangat diperhatikan. Para pendonor yang akan menyumbangkan darahnya akan dipandu oleh PMI Kota Batam dan panitia dengan mengikuti protokol kesehatan. Sasaran kegiatan yaitu masyarakat Kota Batam yang mendaftar secara perorangan ataupun kelompok; komunitas, mahasiswa, organisasi masyarakat, TNI, Polri yang diundang oleh panitia Dosen; Para Dosen dan Mahasiswa di berbagai perguruan Tinggi di Kota Batam.
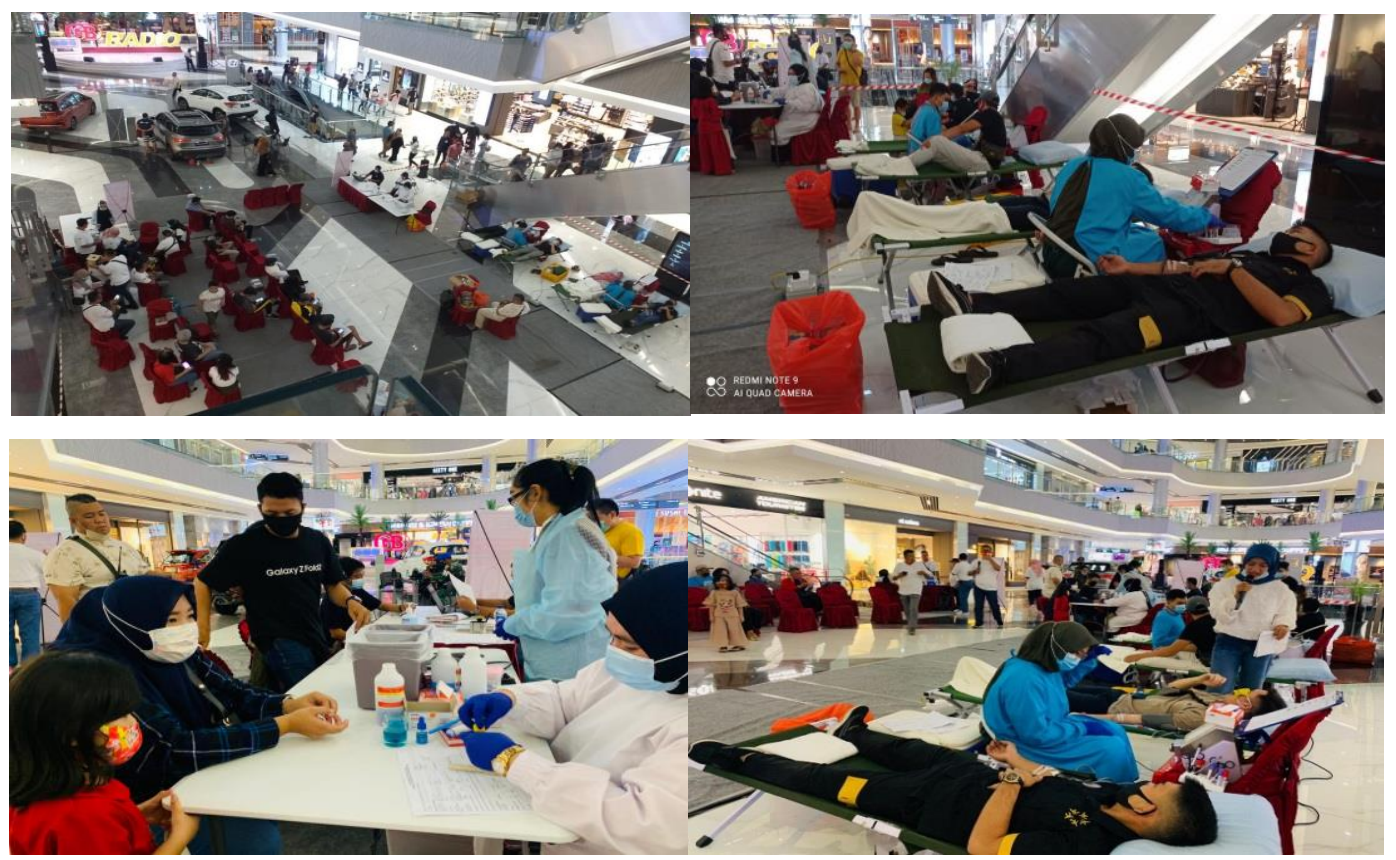

Figur 1. Pelaksanaan kegiatan 


\section{KESIMPULAN DAN SARAN}

Secara umum pelaksanaan kegiatan donor darah "Setetes Darah untuk Kemanusiaan" terlaksana sesuai rencana dan berjalan dengan lancar. Terlaksananya kegiatan ini tentunya tidak lepas dari dukungan berbagai pihak, baik para peserta donor darah, Dosen-dosen, donator, PMI Kota Batam, Polsek Lubuk Baja, panitia dari Universitas Riau Kepulauan (UNRIKA), Universitas Putera Batam (UPB), dan Universitas Ibnu Sina (UIS). Semoga kegiatan sosial donor darah dapat pula terlaksana di masa yang akan datang sebagai wadah sosial untuk kemanusiaan.

\section{REFERENSI}

Aziz, A. 2010. Upaya Menghimpun dan Melestarikan Darah. Bulletin Transfuse Darah. Vol: 27 (279).

Batampos. (2020). Stok Darah di PMI Kota Batam Menipis. https://batampos.co.id/. (diakses 13 Juli, 2020).

Budiningsih, A. 2011. Gambaran faktor-faktor yang mempengaruhi motivasi pendonor sukarela untuk mendonorkan darah di UTD-PMI Kota Medan tahun 2010. [Skripsi]. FKM USU, Medan. Tidak dipublikasikan.

Kurniadin dan Machali, II. (2012). Manajemen Pendidikan: Konsep dan Prinsip Pengelolaan Pendidikan. Terbitan II. Yogyakarta: Ar-Ruzz.

Palang Merah Indonesia (PMI). (2012, Agustus). Serba-Serbi Transfusi Darah. Palangmerah.org. Diakses pada palangmerah.org.

Pribadi, T., Indrayanti, A. L., dan Yanti, E. V. (2018). Peningkatan Partisipasi Masyarakat Dalam Kegiatan Donor Darah Di Palangka Raya. Jurnal Pengabdian Al-Ikhlas, 3(1), $50-58$.

Situmorang, P.R., Sihotang, W.Y., dan Novitarum, L. (2020). Identifikasi Faktor-Faktor yang Mempengaruhi Kelayakan Donor Darah di STIKes Santa Elisabeth Medan Tahun 2019. Jurnal Analis Medika Bioains (JAMBS), 7(2), 122-129.

Swari, R. C. (2020, November 2020). 5 Manfaat Donor Darah bagi Kesehatan Anda. hellosehat.com. Diakses pada hellosehat.com. 